\title{
Imprisoned by intelligence
}

\section{Anathem \\ by Neal Stephenson \\ Atlantic Books/William Morrow: 2008. \\ 800 pp/960 pp. $€ 18.99 / \$ 29.95$}

The divide between science and society is extrapolated to the extreme in Neal Stephenson's novel Anathem. The author, who is well regarded for his vision of science in contemporary and historical settings, creates in his latest work the fictional planet Arbre, which parallels Earth in the very far future.

Following a series of past technological catastrophes for which they were blamed, the planet's scientists, scholars and philosophers - known as the avout - have been forced to live apart from the 'Sæcular world' of society at large. The avout inhabit cloistered compounds, the distinctive clock towers of which are familiar features in most large towns and cities on Arbre. Most high technology is withheld from the avout in case they repeat past disasters. Instead, they spend their robed, austere days engaged in theoretical research and low-tech experimentation using permitted objects, such as telescopes. The avout are not allowed to breed, lest their offspring harbour dangerous levels of intelligence. Rather, they repopulate their numbers with unwanted orphans and those with abilities.

As the avout go about their rituals, the Sæcular world might as well be another planet: its inhabitants chatter on 'jeejahs' (mobile phones) and surf the 'Reticulum' (Internet) when not cheering on sports teams and growing obese on sugary drinks. The two worlds mingle only in strictly controlled circumstances, such as at an annual goodwill festival and in avout-run universities where smarter Sæculars can get a sanitized education. Sæcular artisans may refine existing technology but lack the advanced scientific education to be innovative, so the avout are not dispensable. But it takes an extreme global problem for the Sæcular government to summon the avout to contribute their brain power.

So begins the novel. Anathem centres on a young avout, Fraa Erasmas, who comes of age during a pivotal time in Arbre's history. A starship is orbiting the planet, and its crew, although familiar, do not seem to be friendly. Erasmas and his colleagues are called on to help understand the extraterrestrial threat and fend it off.

The pleasure of reading Anathem derives in part from viewing our own world through the distorted fairground mirror that Stephenson establishes. The language is English with a twist: the word devout morphs to avout, friar to fraa, sister to suur. Euphemistic management speak is bullshyte and a caste of scathing computer technicians is known as the Ita. The distortions are reflected in scientific concepts as well: Occam's razor becomes Gardan's Steelyard. And the great scientific figures of Earth get their Arbre avatars: Plato appears as Protas, Socrates as Thelenes and Archimedes as Carta. As with any decent distortion, the author leaves unexplained many areas of Arbrean society and history that the reader can enjoy filling in.

The story of Erasmas and his friends is an epic adventure that is well paced and exciting. Yet the action is underpinned by serious, carefully researched scientific and philosophical concepts - notably quantum mechanics, parallel universes and the nature of consciousness. Some of the scholarly dialogues take work to follow, but the effort is rewarded. Stephenson credits a number of philosophical and mathematical thinkers in helping him flesh out these fictionalized ideas, including Gottfried Leibniz, Kurt Gödel, Edmund Husserl and Edward Zalta. As the people of Arbre struggle to understand the alien invaders, the author seems most

\section{In Retrospect: Fernel's Physiologia}

\section{The seeds of systems biology were sown 450 years ago by a classic medical text, explains G. Rickey Welch.}

\author{
The Physiologia of Jean Fernel \\ Translated and annotated by \\ John M. Forrester \\ American Philosophical Society: 2003. \\ 636 pp. \$24 (pbk)
}

The Physiome Project, spearheaded by the International Union of Physiological Sciences, aims to generate a framework for understanding the workings of the entire human organism, from genes and proteins to the whole body. A seminal Latin medical text presaged this venture around 450 years ago.

Its author, Jean Fernel (pictured, right), was one of the foremost figures of French Renaissance science and medicine, and the first to use the term 'physiology' in its modern scientific sense. At the time, 'physiologia' denoted the study of nature or natural philosophy. First published in 1542, Physiologia underwent more than 30 reissues, and caused debate in Europe for the next 100 years.

Physiologia, together with Pathologia and
Therapeutice, was one of three volumes that comprised Fernel's crowning work, Universa Medicina. Physiologia set forth a fundamental theory of the operation of the human body: the nature of the wholly healthy human being, all the powers and functions. This flowed into a description of diseases (Pathologia) and their treatments (Therapeutice). Fernel's opus resonates today in the goal of the Physiome Project, which is 'to understand and describe the human organism, its physiology and pathophysiology, and to use this understanding to improve human health'.

In Fernel's time, medical practice centred on the study of body parts in lavishly illustrated anatomy texts, by authors such as Andreas Vesalius. Fernel attacked this 'shallow and easy art', arguing that it lacked holistic principles of causation and function. His answer, Physiologia, is a brilliantly logical treatise. Fernel begins with a philosophical reflection on the appropriate means of analytical attack, and he settles on a top-down method - one that we recognize in today's physiological practice. He then describes all the known anatomical parts of the human organism and develops his notion of a 'comprehensive physiology' Seizing on the Aristotelian principles of deductive reasoning, causal analysis and physics of matter, Fernel demonstrates how the elemental attributes of the body parts are woven into a whole that manifests all the temperaments, humours, powers and faculties of the living being. Although he characterizes the causation of bodily processes within the framework of the 'animal spirits' proposed by the ancient Greek physician Galen, Fernel envisaged such 'spirits' in a real material form, breaking from the irrationality of occultism and magic that had dominated medieval natural philosophy and medicine.

Physiologia constitutes the first complete 
indebted to Roger Penrose's controversial ideas about how the quantum world might impinge on the neurobiology of consciousness.

As a thought experiment in examining the relationship between science and society, and as a cautionary tale about the consequences of its breakdown, Anathem provides much to ponder. In one scene, a scholar quizzes her students about the various stereotypes of the avout that society has harboured. The images are familiar: scientists as loveable, dishevelled Einsteinian boffins; as mystics hoarding the Universe's secrets; as criminally insane desperadoes in white smocks with schemes to take over the world; as highly strung, meddling know-it-alls who simply don't understand the realities of modern life. Although details of the catastrophes that caused the avout to be sequestered are not made clear, it is hinted that tinkering with genetic information, with the structures of atoms and with space-time itself were all factors. Anathem is a shrewd exploration of what might happen if the fear of scientists meddling with things they were never meant to know becomes entirely justified. Jennifer Rohn is a cell biologist at University College London, London WC1E 6BT, UK, editor of LabLit.com and author of Experimental Heart. e-mail: jenny@lablit.com

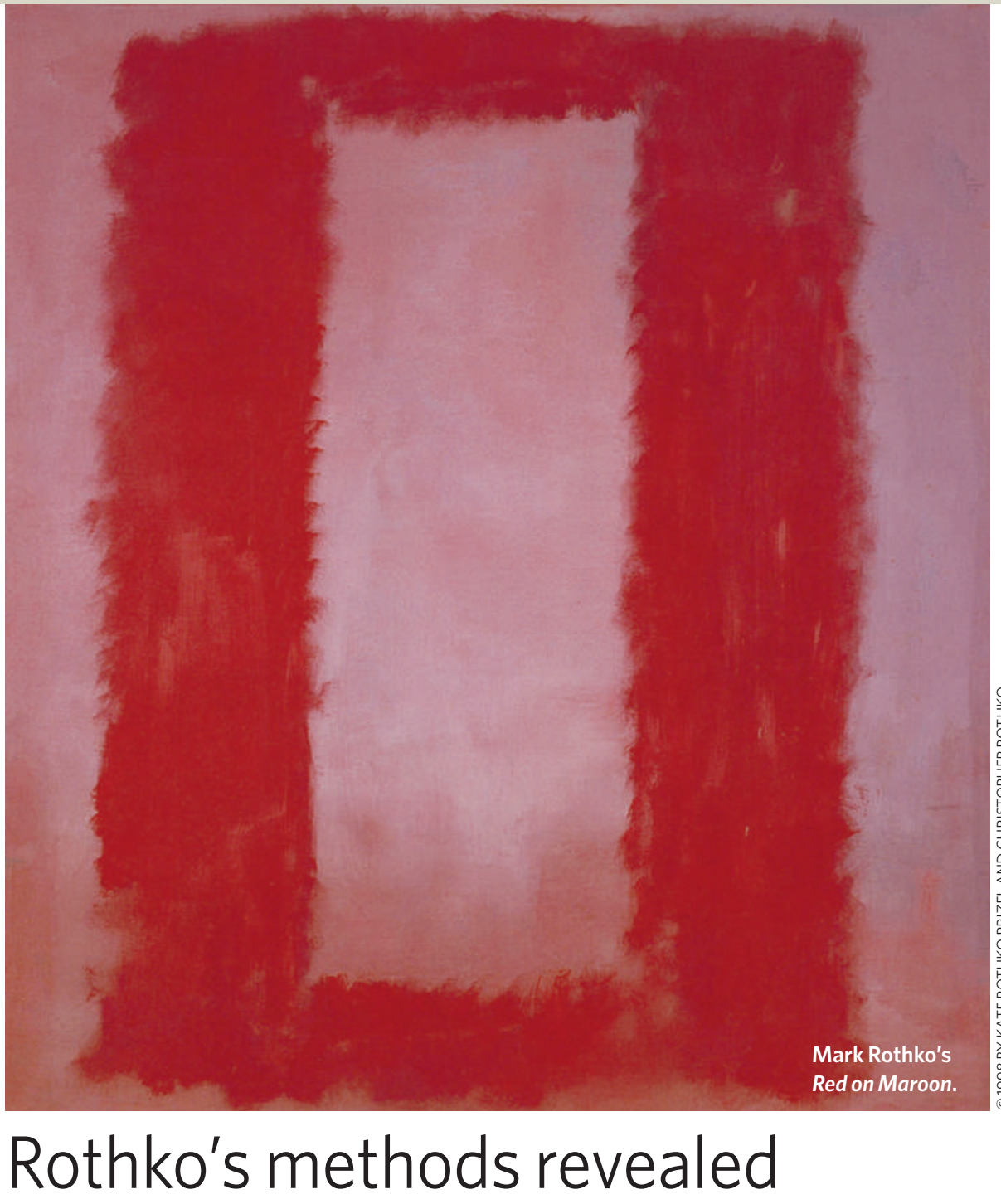

view of what we now call physiology. It is also a forerunner of the systems approach to understanding form and function in living organisms. The field of systems biology today presents us with a challenge similar to that faced by Fernel - to interpret staggering amounts of data depicted in numerous pictographic forms, such as DNA microarray snapshots, proteome network displays and protein-protein interaction maps. Although causation has come to be assigned to a molecule, namely DNA, the way in which we should map from genes to the organism is far from apparent. The Physiome Project embraces the systems-biology movement by showing us how the whole is more than the sum of the parts.

Denis Noble, one of the founders of the project, proffered that "a major part of the future of physiology surely lies in returning to our roots. Higher-level systems biology is, I suggest, classical physiology by another name." We might say that the Physiome Project began at the dawn of the scientific revolution with Physiologia. Fernel's Renaissance thinking pointed the way to a 'universal medicine' that we are now poised to attain.

G. Rickey Welch is professor in the departments of biological sciences and history at the University of Maryland, Baltimore, Maryland 21250, USA. e-mail:welch@umbc.edu

\section{Rothko: the Late Series \\ Tate Modern, London \\ Until 1 February 2009}

Mark Rothko's Seagram murals, commissioned in 1958 to decorate the Four Seasons restaurant in the Seagram Building in New York, are famous for their layers of translucent and opaque paints that produce a luminous and ephemeral quality.

Rothko was notoriously secretive about his methods, refusing to let even his studio assistants watch him paint. Yet the clues he left within the murals have informed conservators of the variety of materials he used and his layering techniques that were innovative for the time.

Conservators at the Tate Modern have studied the murals using cutting-edge techniques in collaboration with researchers at MOLAB, an Italian organization that provides technical support to European conservation projects. They investigated the chemistry of microgram samples of paint using mass spectrometry, and probed the structure of layers with high-resolution electron microscopy. Ultraviolet images reveal Rothko's brush work, each layer made from a unique medium that fluoresces differently.
Their research shows that Rothko used materials far beyond the conventional range sold for artists, modifying the properties of oil paints to achieve the flow, drying time and colours he needed. He used synthetic substances such as oil-modified alkyd and acrylic resins alongside traditional materials, including egg, glue and dammar resin, which are fast-drying and allowed him to apply subsequent layers within hours. Resins increased the viscosity of the mixtures so the paints could be diluted without losing their coherence. Rothko also applied phenol formaldehyde to prevent layers from blending into one another. Each mural differs with regard to its paint mixture or the layering sequence, suggesting that Rothko constantly experimented.

The paintings are fragile, prone to damage by handling, and various components in the layers may react and age differently. Rothko chose not to apply varnish, which would have destroyed his subtle effects of gloss and matt variation, and he did not want to exhibit his creations framed behind glass. Knowledge of the materials present in the murals will help conservators develop bespoke techniques to protect them for future generations.

Jane Qiu is a writer based in Beijing and London. e-mail:jane@janeqiu.com 